\title{
Astana experience: Department of Oncohematology and Bone Marrow Transplantation, National Research Center of Oncology and Transplantation
}

Vadim M. Kemaikin, Anastasiya A. Olifirovich, Alexandr V. Kolesnev, Anatoliy V. Nemerovchenko, Ruzal F. Vildanova, Olga V. Gainutdinova, Adiya A. Tusipova, Ayauzhan E. Esimbekova, Aliya K. Baimursina, Ayzat S. Suleimenova, Olga O. Lesechko, Gulnaz D. Ansatbaeva, Mariya S. Alimbetova

Bone Marrow Transplantation Department, National Research Center for Oncology and Transplantation, Astana, Republic of Kazakhstan

Dr. Vadim M. Kemaikin, Chief, BMT Department, National Research Centre for Oncology and Transplantation, Kerey, Zhanibek Khanov st., 3, Astana, 010000, Republic of Kazakhstan
Phone: +7 7172702941

E-mail: hematology.astana@gmail.com

\section{Summary}

The Unit of Oncohematology and Bone Marrow Transplantation (BMT) was arranged on basis of the Republican Research Center of Hospital Emergencies SC (Astana, Republic of Kazakhstan) in August 2010. Since July 2014, a Clinical Department with 69 beds was arranged, and National Research Center for Oncology and Transplantation SC was arranged. From 2010 to 2016, the modalities of hematopoietic stem cell transplantation have been advanced, from autologous BMT to allogeneic hematopoietic stem cell transplants (HSCT) from matched donors (33\%), and haploidentical HSCTs (43\% in 2016), a total of 186 transpants. Bone marrow was used as a source of stem cells in 71 cases (71 donors for allo-HSCT in 69 recipients), whereas peripheral stem cells were harvested in 73 cases ( 15 donors for 15 recipients of allo-BMT, and 58 marrow harvests for autologous BMT).
In particular, our BMT clinic and Bone Marrow Donor Registry developed with invaluable support and contribution by the leading specialists from R. Gorbacheva Memorial Research Institute of Children Oncology, Hematology and Transplantation at the St. Petersburg. This system of education and training allowed to arrange an effective HSCT structure within 3 years. This assistance was performed in order to consult severe patients, arrange optimal transplantation regimens, analyze difficult clinical cases, perform master classes and conferences.

\section{Keywords}

Hematopoietic stem cell transplantation, clinical advancements, Astana, Republic of Kazakhstan.

\section{Introduction}

The Unit of Oncohematology and Bone Marrow Transplantation (BMT) was arranged on basis of the Republican Research Center of Hospital Emergencies SC (Astana, Republic of Kazakhstan) in August 2010, using previous clinical expe- rience of the regional hematologists. At the beginning, our unit consisted of ten hospital beds for chemotherapy of leukemia and lymphomas. First bone marrow transplantation in Kazakhstan was performed just on the basis of our specialized unit. Time sequence of our main advances is shown in Table 1. 
Table 1. Main steps in development of Oncohematology Unit

\begin{tabular}{|l|l|}
\hline 02.08 .2010 & Inauguration of the Department \\
\hline 29.12 .2010 & Auto-HSCT in myeloma disease \\
\hline 07.06 .2011 & Allogeneic HSCT, related \\
\hline 08.06 .2011 & Autologous HSCT in lymphoma \\
\hline 09.09 .2011 & Haploidentical HSCT \\
\hline 22.09 .2013 & Opening transplantation unit (6 beds) \\
\hline 02.09 .2014 & Allogeneic HSCT from unrelated donor \\
\hline
\end{tabular}

Invaluable support and contribution to the development of the BMT Unit should be mentioned. Our activities were supported by Professor Boris Afanasyev, Director, R. Gorbacheva Memorial Research Institute of Children Oncology, Hematology and Transplantation at the St. Petersburg I. Pavlov State Medical University. Several leading specialists from the Gorbacheva Institute, e.g., Professor Alexander D. Kulagin, Dr. Sergey N. Bondarenko, Dr. Vladimir N. Vavilov worked hardly at Astana, in order to consult severe patients, arrange optimal transplantation regimens, analyze difficult clinical cases, perform master classes and conferences. This collaboration has been sufficiently promoted by Dr. Irina Pivovarova whose contribution to these advances should be highly evaluated.

Since 01.03.2013, the Department was rearranged to the Unit of Hemoblastoses, Hematopoietic Aplasias and BMT, followed by extension to 25 beds, with appropriately trained staff. The unit is a part of Hematology and Transfusiology Department.
Deep renovation of the hospital building (April to September 2013) resulted into opening of aseptic wards with laminar air flow, including BMT unit with six beds and an intensive care unit of four hospital beds.

In September 2013, the Institute of Children Oncology, Hematology and Transplantation (St. Petersburg, Russia), together with our Department, performed the VII Memorial R. Gorbacheva International Symposium with a main topic: $\mathrm{He}$ matopoietic Stem Cell Transplantation in Children and Adults. This event has promoted further development of BMT in Republic of Kazakhstan, and broadening of international cooperation in the field. Due to these advances, Kazakhstan first appeared at the EBMT map, with a total of 46 transplants in 2013 (Fig. 1). The Memorial Symposium attracted prominent specialists from Europe and USA (Fig. 2, 3). b
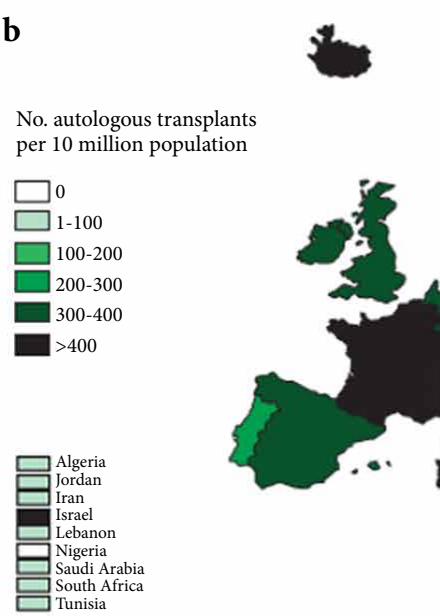

2011
HSCT - rates Europe 2013

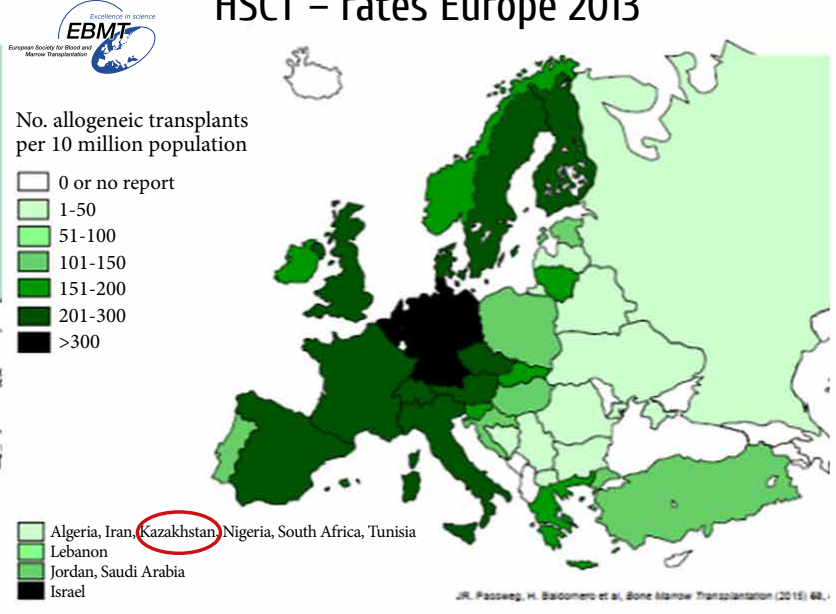

2013

Figure 1. Allogeneic stem cell transplants per 10,000,000 inhabitants: an EBMT map for 2013 (EBMT Report, 2013). 


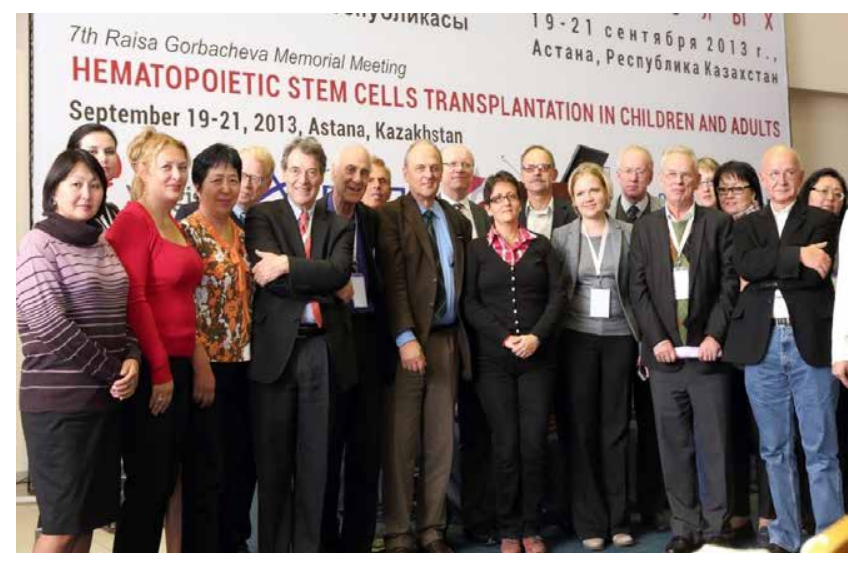

Figure 2. Participants at the VII R. Gorbacheva Memorial International Symposium in Hematology and transplantation in Astana (September 2013).

Since July 4, 2014, a Clinical Department with 69 beds was arranged, and the Centre was renamed to the National Research Centre for Oncology and Transplantation SC. An oncohematological and BMT Department consisted of a Transfusion Unit and Oncohematology Unit with an intensive care ward (4 beds). 20.09.2016, the Department was rearranged once again, with a Unit of Oncohematological Resuscitation and Intensive Care for 6 beds established.

\section{Clinical activities}

Composition of hematological disorders treated at the Department changed over years, however, with acute leukemias (AL) taking a leading place $(54.8 \%)$. Meanwhile, this ratio is increased by $10 \%$ in 2015 , as compared to 2013 , with increased admittance of the patients with acute lymphoblastic leukemias (increase by $16.6 \%$ against 2013 ), mainly, due to introduction of continuous treatment protocols, including high-dose consolidation phase.

Since 2016, we noted higher admission for the patients with acute promyelocytic leukemia, due to improved diagnostics of this leukemia type, e.g., molecular genetic studies performed by FISH assays at the laboratory in St. Petersburg (Russia). The most significant admittance growth was for bone marrow harvesting, i.e., from 9 cases in 2013 to 55 in 2016, due to establishment and development of bone marrow transplantation in the country.

Along with leukemias, we observed a significant increase in hospitalized patients with lymphoproliferative disorders is, i.e., with non-Hodgkin's lymphomas (from 18 to 85 cases), Hodgkin's disease (from 8 to 60 cases), and with multiple myeloma (from 23 to 100 subjects).

\section{Bone marrow transplantation}

The first bone marrow transplantation at our clinic was performed in 2010. In further time, a weak growth in HSCT was noted, i.e., only six in 2011 (including 1 allogeneic related, and 1 haploidentical; nine, in 2012 (5 allogeneic and 4, autologous). Since 2013, after opening a clean block ( 6 beds), we have sufficiently increased the BMT number, i.e., 18 BMT

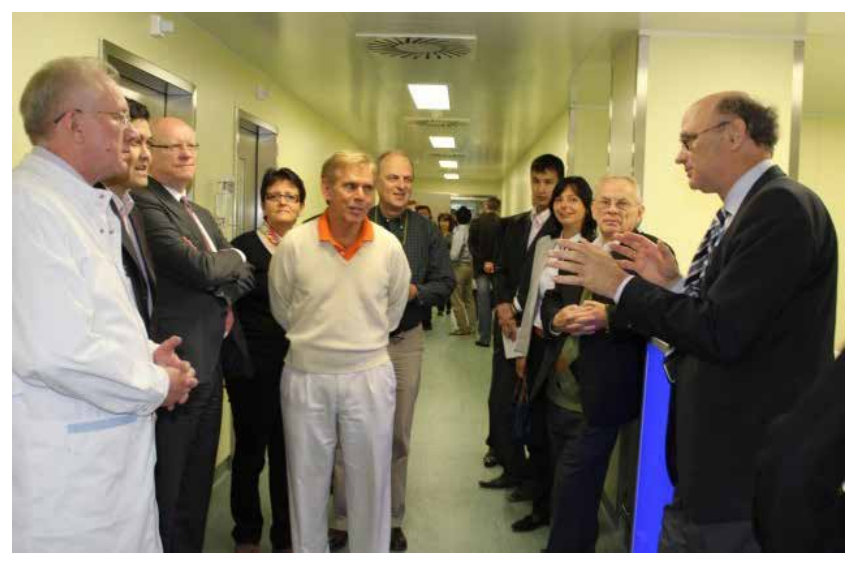

Figure 3. International team of hematologists visiting the new BMT Department in Astana (September 2013).

(5 auto, 9 allogeneic compatible, and 4 haploidentical transplants); in 2014, 46 (5 auto-, 9 allogeneic and 4 haploidentical). During next years, a stabilization in HSCT amounts is observed: 2015, 54 BMT, 2016, 52 BMT (Fig.4).

Bone marrow was used as a source of stem cells in 71 cases (71 donors for allo-HSCT in 69 recipients), whereas peripheral stem cells were harvested in 73 cases ( 15 donors for 15 recipients of allo-BMT, and 58 marrow harvests for autologous BMT). Poor stem cell mobilizing ability was revealed in multiple myeloma (1 case after Cyclophosphamide injections) and 2 lymphoma patients (DHAP-treatment). Better HSC mobilization was performed with Etoposide (in myeloma case), and in 1 patient, G-CSF was applied as hemostimulant.

In 40 cases, both primed BM and PBSCs were infused to the patients. Peripheral stem cell harvesting was performed at the Center of Blood Transfusion in Astana by means of obsolete collection devices (Haemonetics MCS+). At initial steps of our transplantation activities, we obtained inferior stem cell harvests, therefore infusing additional amounts of native bone marrow cells. However, the situation has changed since 2016, after installation of new equipment (Terumo Spectra Optia), we are able to yield sufficient amounts of peripheral stem cells for transplantation.

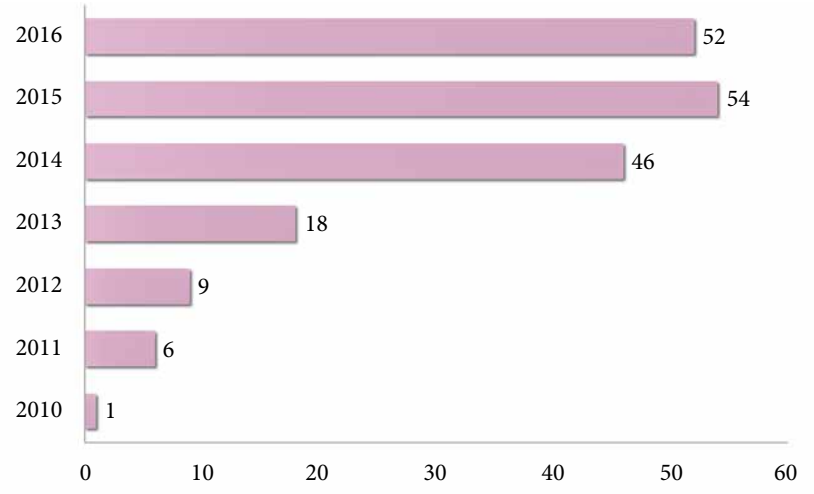

Figure 4. Total BMT figures by years at the Center of Oncohematology and Bone Marrow Transplantation (Astana, Kazakhstan). A total of 186 transplants were performed. Abscissa, number of transplants; ordinate, year of observation. 
The total amounts of HSCT do not meet appropriate Kazakhstan requirements. As seen from EBMT Reports, most European countries perform over 100 transplants per 10 Mio persons. To reach this level, we should make about 200 transplants annually (Table 2).

\section{Table 2. Estimated BMT requirements for Republic of Kazakhstan}

\begin{tabular}{|l|c|c|c|}
\hline Type of disorder & Number of primary patients & $\begin{array}{c}\text { Estimated BMT requirement, } \\
\text { \% (EBMT data) }\end{array}$ & $\begin{array}{c}\text { BMT requirement } \\
\text { (absolute numbers) }\end{array}$ \\
\hline Acute lymphoblastic leukemia & 48 & 60 & 29 \\
\hline Acute myeloblastic leukemia & 64 & 75 & 48 \\
\hline Aplsatic anemias & 47 & 30 & 14 \\
\hline Myelodysplastic syndrome & 48 & 25 & 12 \\
\hline Non-Hodgkin's lymphoma & 21 & 55 & 12 \\
\hline Hodgkin's lymphoma & 11 & 55 & 6 \\
\hline Multiple myeloma & 48 & 65 & 31 \\
\hline Total number & & & 152 \\
\hline
\end{tabular}

\section{Donor availability}

The ratio of haploidentical transplants performed in our clinic is increased from 4 BMTs (2013) to 23 transplants in 2015. (Fig. 5). A significant growth in haplo-HSCT is noted in 2015 (23 BMTs, 43\%) as compared to 2014 (9 BMTs, 19\% of total). However, a lack for HLA-identical donors was evident. According to ASBMT, about 70\% of the patients with malignant blood disorder do not have available HLA-identical related donor [1]. A median tine for searching an unrelated donor is ca. 4 months in $50-60 \%$ of cases. This term is too long, due to risk of the disease relapse.

There is an imbalance for different BMT types (Fig. 6). The number of auto-BMT, according to EBMT data, twice exceeds allo-BMT numbers. Relative number of auto-BMT (24\% in 2015) is minimal at the Oncohematology and Bone Marrow Transplantation Department, compared to other types. Haplo-BMT (43\%) and allogeneic BMT (33) are prevailing here. Such an imbalance occurs due to deficiency of transplantation beds, low activities of regions by the patient stratification and their selection for bone marrow transplantation.

Therefore, we considered arrangement of a local hematopoietic stem cell donor registry as a possible solution of this problem. This Registry was established in 2013. Consolidated registry of Russian Federation and Kazakh Republic have been created year later, and, currently, 5500 potential donors from Kazakhstan are introduced to this database. In 2014, a first HLA-identical donor from Kazakhstan was activated in this Registry, and the first unrelated allogeneic transplantation from this donor was performed 02.09.2016 at out Department. Arrangement and advances of the Bone Marrow Donor Registry in our Republic are closely associated with collaboration and advices from Dr. Alexander L. Alyansky, Chief of a big Donor Registry at the R. Gorbacheva Research Institute of Children Oncology, Hematology and Transplantation (St. Petersburg).

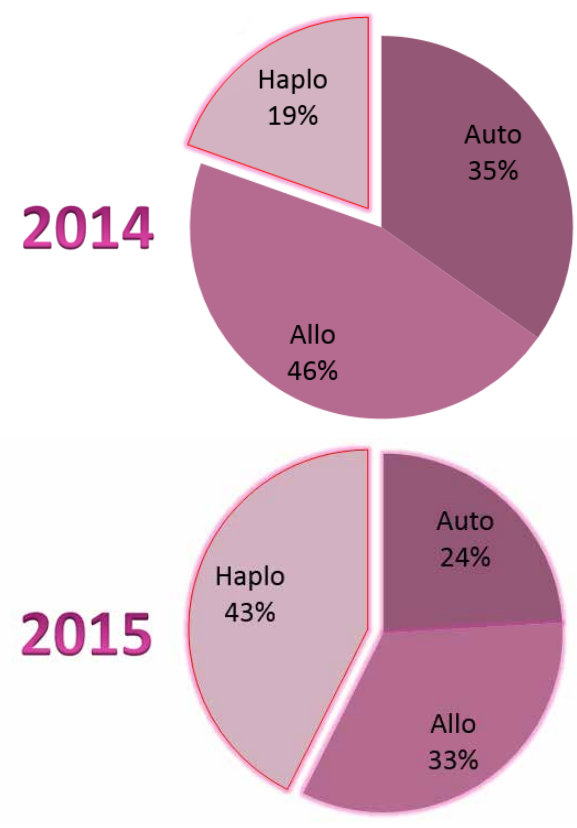

Figure 5. Ratios of different transplant types.

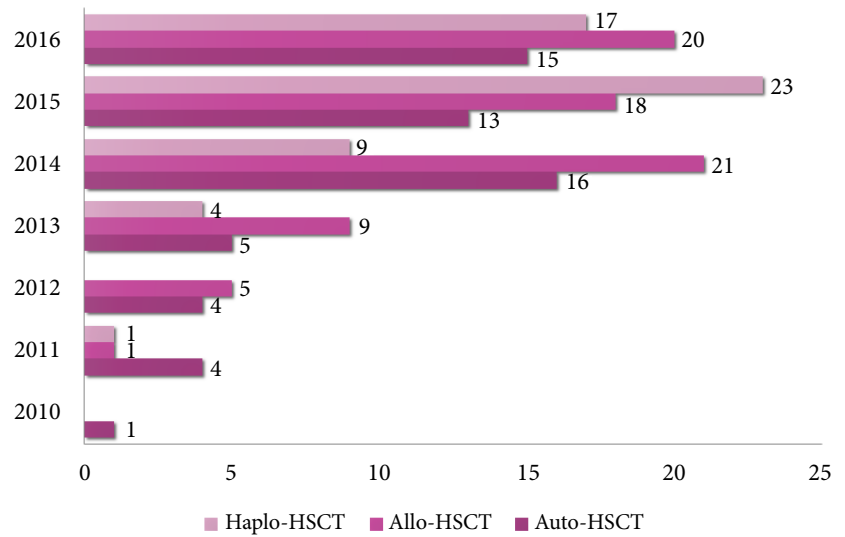

Figure 6. Time dynamics of BMTs by several years, with respect to the BMT types. 


\section{Clinical results of BMT procedures}

In 2015, we have performed analysis of total survival among the BMT patients (Fig. 7). This analysis shows a significantly higher total survival in a group of patients after allo-BMT performed in the $1^{\text {st }}$ remission, as compared to survival in

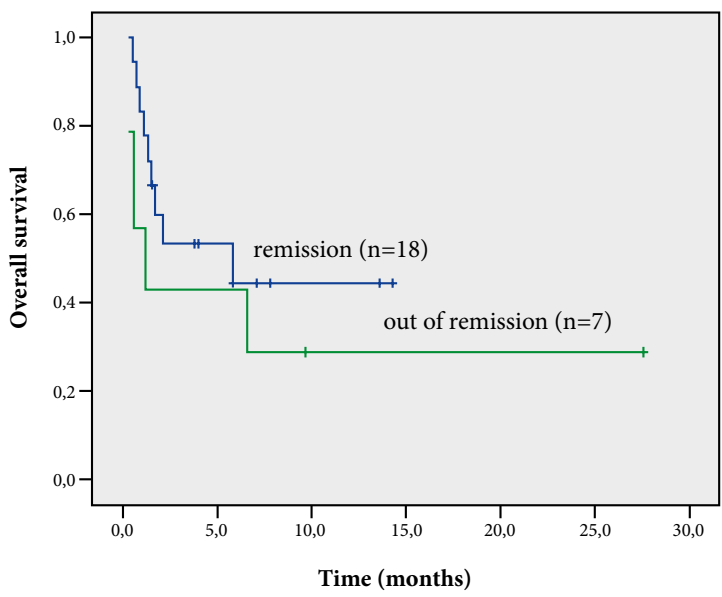

\section{Haplo-HSCT}

In acute leukemia $(n=25)$ the group after allogeneic BMT carried out in the absence of remission, i.e., $59 \%$ vs $20 \%$. Overall survival after haploidentical BMT is also higher in the patients transplanted in $1^{\text {st }}$ remission, as compared to the patients, undergoing BMT out of remission ( $41 \%$ vs $23 \%)$.

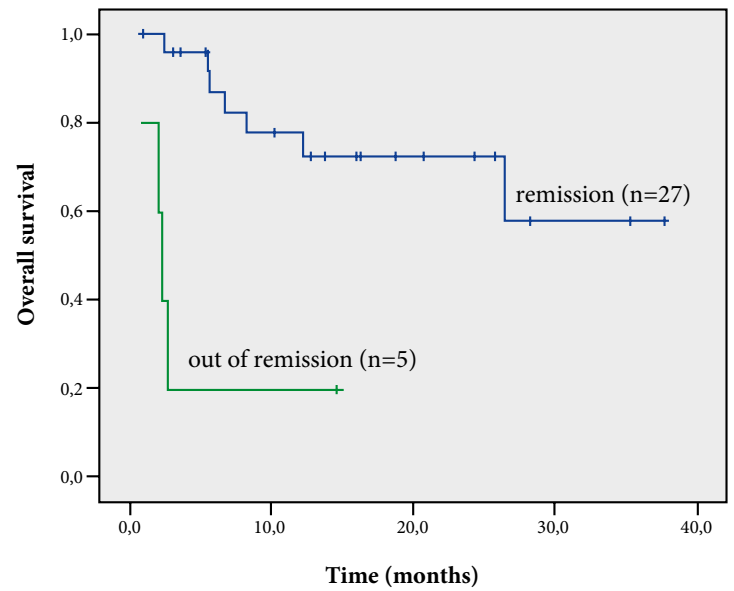

Allo-HSCT

In acute leukemia $(n=32)$

Figure 7. Total survival after allogeneic BMT and haplo-BMT in the patients with acute leukemias dependent on the state of disease by the time of transplant.

Overall survival (OS) was also determined in a group of patients with acute myeloblastic leukemia. We compared 3 patient groups, Group1, patients receiving chemotherapy only; Group 2 obtained BMT in remission, and Group3, patients receiving an off-remission BMT (Fig.7). Overall survival among patients from the $2^{\text {nd }}$ group was sufficiently higher than for groups 1 and 3, i.e., 10\% vs 60\%. However, OS among the patients after BMT beyond remission was twofold higher than among subjects getting chemotherapy only (20\% vs $10 \%)$.

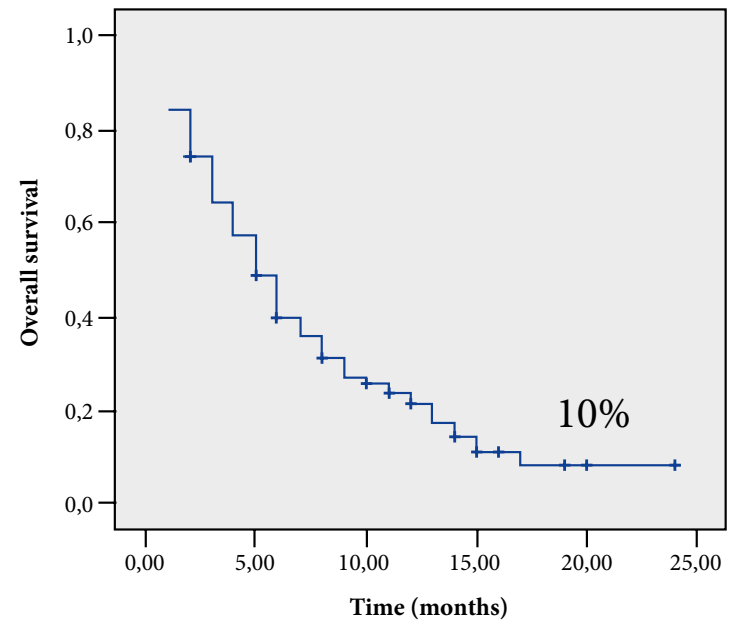

Chemotherapy in regions
Preliminary analysis of overall survival among acute leukemia patients (observed for 30 months in haplo-HSCT, or 40 months in allo-HSCT) has shown an important role of the disease status by the time of BMT, thus being in full accordance with available international data. Our results should be further analysed for 5 -year survival in a group of $\geq 30$ patients $[2,3,4]$.

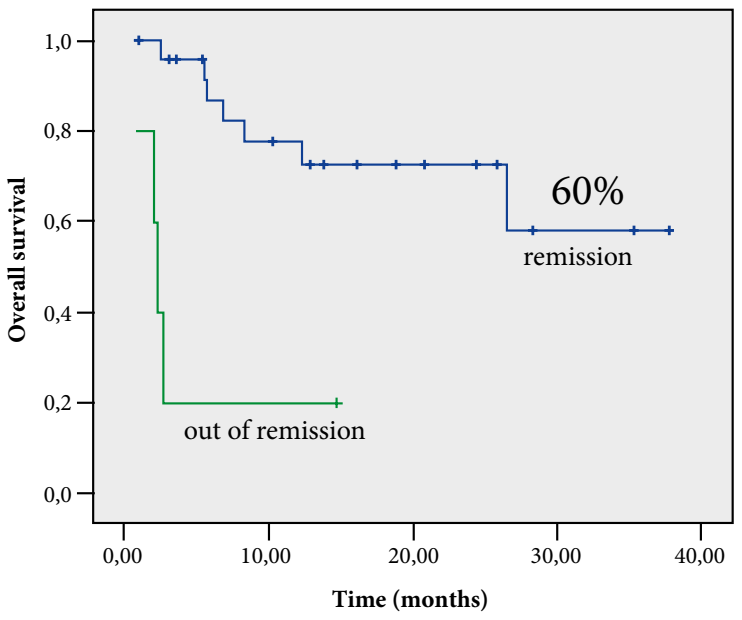

Allo-HSCT at National Research Center (Astana)

Figure 8. Overall survival among patients with acute leukemias (AML and ALL), when performing standard chemotherapy (left) and allo-HSCT at our BMT Department (right). 
Despite the arrangement of 'clean unit', and BMT numbers increased to 54 in 2015, high requirements for transplantation remain in the country. E.g., according to statistical data (Table 2), 152 patients in Kazakhstan need BMT yearly, either allogeneic or autologous procedure. Acute leukemias (77 BMTs per year) are most common at our Department, including 29 ALL cases and 48 AML patients. Multiple myeloma takes next position (31 BMT annually), followed by aplastic anemia (14 BMTs), myelodysplastic syndromes $(n=12)$ and non-Hodgkin's lymphomas $(\mathrm{n}=12)$, as well as Hodgkin's lymphoma (6 BMTs yearly). To cover these requirements, we are planning increase in patient places (beds), with subsequent expansion of the 'clean' space from 6 to 15 beds.

\section{Cooperation with clinics abroad}

A big contribution to development of the Oncohematology Department and BMT activity was made by the staff of the R. Gorbacheva Research Institute of Children Oncology, Hematology and Transplantation at the First I. Pavlov State Medical University (St. Petersburg, Russia), having been provided over last years. Over 2014-2015, we have trained in St. Petersburg four clinicians in Hematology at a postgraduate course Current Hematology and Bone Marrow Transplantation; two clinical laboratory doctors for diagnostics of malignant blood disorders, trained a laboratory doctor in clinical cytogenetics. Our collaborators from Gorbacheva Institute have teached a specialist in hematopoietic stem cells harvesting, treatment and cryoconservation; performed educational courses for 5 clinical hematolologists at the VIII and IX R. Gorbacheva Memorial Symposia (2014, 2015, St. Petersburg).

Moreover, some specialists from St. Petersburg R. Gorbacheva Memorial Institute performed in Kazakhstan several seminars and master classes over 2014, e.g., in flow cytometry for detection of minimal residual disease (Babenko Elena V., 2014); arrangement of hematological services in Kazakhstan (Morozova Elena V., Bondarenko Sergey N., Darskaya Elena I.); a 4-week tutorial concerning Basics of Modern Diagnostics and Treatment in Oncohematology which took place in Almaty (Kazakhstan).

A special longitudinal cooperation is performed in the field of arrangement of a Bone Marrow Donor Registry in Kazakhstan Republic. A common Russian-Kazakh donor search platform is arranged in order to recruit bone marrow donors from Russian Registry for Kazakh patients.

Some other tutorials were performed in 2015, including a school for paroxysmal nocturnal hemoglobinuria (Babenko E. V., Kulagin A. D., held in St. Petersburg), a master class by E. V. Babenko concerning immune phenotyping of PNH markers (April 2015, Astana, Kazakhstan); an expert council on invasive fungal invasions in hematology (13 May, 2015, Research Institute of Pediatrics and Children Surgery, Prof. K. O. Omarova, N. N. Klimko, PhD M. O. Popova). A tutorial "Hematopoietic stem cell transplantation in the children with oncohematological diseases and orphan diseases" was performed on May 25-30, 2015, in Astana, led by Dr. S. N. Bondarenko), followed by a master class: Arrange- ment of a Bone Marrow Donor Registry (May 26-28, 2015, Astana, led by Dr. A. L. Alyansky).

\section{Further prospectives}

Future cooperation between the $1^{\text {st }}$ St. Petersburg State Medical I. Pavlov University and hematological institutions in St. Petersburg and Kazakhstan in the field of hematopoietic transplantation should be developed in the abovementioned directions:

1. Hematopoietic transplantation in pediatric practice and adult patients.

1) Further development of diagnostic base in oncohematology (morphology, immunohistochemistry, immune phenotyping, cytogenetics, molecular diagnostics).

2) Unified and improved diagnostic and therapeutic protocols, in order to assess and treat tumor and non-tumor blood diseases.

3) Orphan dieases (diagnostics, registries, bone marrow transplantation, target therapy).

2. Functioning of a common Bone Marrow Donor Registry.

Our plans for the nearest future are connected with meeting the requirements of Kazakh patients in transplantation assistance, e.g., an increase of clinical facilities by 5 hospital beds, and opening a special block for therapy of lymphoproliferative disorders with 15 beds, as well as expansion of critical care unit to 9 beds. Increasing number of patients needs arrangement of outpatient service and polyclinics.

\section{Conflicts of interest}

The authors have no conflict of interest to declare.

\section{References}

1. Bayraktar UD, Champlin RE, Ciurea SO. Progress in haploidentical stem cell transplantation. Biol Blood Marrow Transplant 2012; 18:372-380.

2. Olifirovich A, Pivovarova I, Kemaykin V, Klodzinskiy A, Nemerovchenko A, Tussipova A, Vildanova R, Sataeva M, Kolesnev A, Iskakova A. Remission at secondary acute myeloid leukemia after haploidentical stem cells microtransplantation (a clinical case); Abstract XXXV World Congress International Society of Hematology, Sept. 4-7, Beijing, China, 2014: 133, EP-05-001.

3. Pivovarova IA, Klodzinsky AA, Kemaikin VM, Olifirovich AA, Kolesnev AV, Iskakova AM, Sataeva MS. Lethality trends after haploidentical hematopoietic stem cell transplantation. Kazakhstanskaya Transplantologiya, 2014; №1:46-53.

4. Vildanova R, Pivovarova I, Klodzinskiy A, Kemaikin V, Kolesnev A, Sataeva M, Iskakova A, Olifirovich A, Tussipova A, Nemerovchenko A. BeEAM as conditioning regimen for haploidentical bone marrow transplantation in patients with Ph-positive ALL (two case reports); Abstract XXXV World Congress International Society of Hematology, Sept. 4-7, Beijing, China, 2014: 124, EP-04-001. 


\section{Опыт Астаны: отдел онкогематологии и трансплан- тации костного мозга, Национальный исследова- тельский Центр онкологии и трансплантации}

Вадим М. Кемайкин, Анастасия А. Олифирович, Александр В. Колеснев, Анатолий В. Немеровченко, Рузаль Ф. Вильданова, Ольга В. Гайнутдинова, Адия А. Тусипова, Аяужан Е. Есимбекова, Алия К. Баймурзина, Айзат С. Сулейменова, Ольга О. Лесечко, Гульназ Д. Ансатбаева, Мария С. Алимбетова

Департамент трансплантации костного мозга, Национальный научный центр онкологии и трансплантации, Астана, Республика Казахстан

\section{Резюме}

Отделение онкогематологии и трансплантации костного мозга (ТКМ) было организовано на базе Республиканского научного центра неотложной медицинской помощи (Астана, Республика Казахстан) в августе 2010 г. С июля 2014 г. организован клинический департамент на 60 коек, и было учреждено АO «Национальный научный Центр онкологии и трансплантации». С 2010 по 2016 гг. начали внедряться различные типы трансплантации гемопоэтических стволовых клеток (ТГСК) - от аутологичной ТКМ до аллогенной ТГСК от совместимых доноров (33\% в 2016 г.) и гаплоидентичной ТГСК (43\% от общего числа пересадок в 2016 г.). Всего с 2010 г. в отделении проведены 186 ТГСК. Костный мозг в качестве трансплантата использовали в 71 случае (71 донор для алло-ТГСК 69 реципиентам), тогда как периферические стволовые клетки заготавливали в 73 случаях (15 доноров для алло-ТГСК), и 58 заготовок костного мозга для аутологичных ТКМ).
Особый вклад в развитие нашей клиники ТКМ и регистра доноров костного мозга внесли ведущие специалисты НИИ детской онкологии, гематологии и трансплантологии им. Р. М. Горбачевой в Санкт-Петербурге. Эти мероприятия по обучению и образованию позволили организовать эффективную структуру для ТГСК за 3 года. Такая помощь оказывалась по линии консультирования тяжелых клинических случаев, назначения оптимальных режимов трансплантации, анализа сложных клинических случаев, в виде конференций и мастер-классов.

\section{Ключевые слова}

Трансплантация гемопоэтических стволовых клеток, организация клиники, Астана, казахстанский опыт. 